\title{
Association between Dietary Habits and Prehypertension among Indonesian Young Adults at Prof. Dr. R. D. Kandou Hospital Manado
}

\author{
Ribka Wowor
}

Faculty of Public Health, Sam Ratulangi University Manado

Email: ribkaladywowor@gmail.com

\begin{abstract}
Prehypertension is a warning sign, early in age which denotes the risk of hypertension later on in life. Clinical and academic challenges of medical students may have adverse effect on their lifestyle, predisposing vulnerable subjects to elevated blood pressure. This study was aimed to determine the association between dietary habits and prehypertension among Indonesian young adults in Manado. This was an analytical study with a cross-sectional study. Subjects were 111 medical students (undergraduate and postgraduate) aged between 20-30 years, of either sex. A pre-tested questionnaire was used to elicit the details on physical activity, family history of hypertension, tobacco use, and dietary habits. According to JNC-7 guidelines, a systolic blood pressure (SBP) of 120 to $139 \mathrm{mmHg}$ and/or diastolic blood pressure (DBP) of 80 to $89 \mathrm{mmHg}$ is considered as prehypertension. Of the 111 subjects, $22.5 \%$ showed blood pressure levels within the range of prehypertension. Chi-square analysis revealed that junk food consumption $(\mathrm{OR}=3,152 ; 95 \% \mathrm{CI}=1,253-7,925 ; P=0,023)$, and soft drink consumption $(\mathrm{OR}=4,747 ; 95 \%$ $\mathrm{CI}=1,797-12,539 ; P=0,002)$ were the risk factors of prehypertension. Conclusion: Dietary habits were associated with the prehypertension among young adults in Manado.
\end{abstract}

Keywords: dietary habits, prehypertension, young adults

\begin{abstract}
Abstrak: Prehipertensi merupakan tanda peringatan dini akan resiko terjadinya hipertensi di kemudian hari. Mahasiswa kedokteran memiliki kesibukan studi terutama pada masa kepaniteraan klinik di Rumah Sakit. Tuntutan dalam pendidikan dan pelayanan sekaligus di RS berdampak terhadap pola aktivitas mereka sehari-hari sehingga dapat memengaruhi tekanan darah. Penelitian ini bertujuan untuk mengetahui hubungan antara diet (konsumsi makanan dan minuman) dengan kejadian prehipertensi pada mahasiswa kedokteran Univrsitas Sam Ratulangi. Jenis penelitian ialah analitik dengan desain potong lintang. Hasil penelitian mendapatkan 111 mahasiswa kedokteran peserta P3D dan PPDS (calon spesialis) berusia antara 20-30 tahun sebagai subyek penelitian. Dilakukan pemeriksaan tekanan darah dan berat badan. Penentuan kebiasaan makan ditetapkan berdasarkan hasil pengisian kuesioner. Definisi prehipertensi berdasarkan kriteria JNC 7 yaitu tekanan darah sistolik lebih dari $120 \mathrm{mmHg}$ tapi kurang dari 140 $\mathrm{mmHg}$, dan atau tekanan darah diastolik lebih dari $80 \mathrm{mmHg}$ tapi kurang dari $90 \mathrm{mmHg}$. Uji Chisquare dilakukan untuk melihat hubungan antara konsumsi junk food dan soft drink dengan kejadian prehipertensi dan didapatkan adanya hubungan antara konsumsi junk food (OR=3,152; 95\% CI=1,253-7,925; $P=0,023)$, dan soft drink $(\mathrm{OR}=4,747 ; 95 \% \mathrm{CI}=1,797-12,539 ; P=0,002)$ dengan kejadian prehipertensi pada subyek dewasa muda. Simpulan: Diet (konsumsi junk food dan soft drink) berhubungan dengan kejadian prehipertensi pada subyek dewasa muda di Manado.
\end{abstract}

Kata kunci: diet, prehipertensi, dewasa muda

Prehypertension is a warning sign, early in age which denotes the risk of hypertension later on in life. ${ }^{1}$ It has also been noted that even asymptomatic adolescents with mild blood pressure elevation can have target organ damage. ${ }^{2,3}$ People with prehyper- 
tension have a three-fold risk of developing hypertension compared with normotensive people. ${ }^{4}$ Prehypertension is often linked to target organ damage, such as early arteriosclerosis, small vascular damage, coronary artery calcification, vascular remodeling, and left ventricular hypertrophy. ${ }^{5,6}$ In India, hypertension is responsible for $57 \%$ of the deaths caused due to stroke and 24\% caused due to coronary heart disease. ${ }^{7}$

Clinical and academic challenges of medical students may have adverse effect on their lifestyle, predisposing vulnerable subjects to elevated blood pressure. ${ }^{8}$ Identifying risk factors for prehypertension in younger adults can help in giving intervention to prevent or minimize prehypertension progression to advanced stages of hypertension. This study was conducted to determine the association between dietary habits and prehypertension among medical students in Sam Ratulangi University, Manado

\section{METHODS}

This study was conducted in August 2018 at the Departement of Internal Medicine, Prof. Dr. R. D. Kandou Hospital Manado, North Sulawesi Province. This was an analytical study with a crosssectional design performed on 111 medical students (undergraduate and postgraduate) aged between $20-30$ years, of both sexes. In study subjects, blood pressure and body weight were measured. According to JNC7 guidelines, a systolic blood pressure (SBP) of 120 to $139 \mathrm{~mm} \mathrm{Hg}$ and/or a diastolic blood pressure (DBP) of 80 to 89 $\mathrm{mm} \mathrm{Hg}$ is considered as prehypertension. ${ }^{2}$ A sphygmomanometer Riester was used to measure the blood pressure performed on sitting position from the left arm of all patients, twice with a 10 minutes rest in between. The mean of both values was taken as the subject's blood pressure.

A pre-tested questionnaire was used to elicit the details on family history of hypertension, and dietary habits. Frequency of intake of junk foods was defined as more than/less than two times in a week. Junk food was defined as food that is high in calories and low in nutritional content including food items like potato chips, cold drinks, etc. ${ }^{9}$

The Chi-square test was used to determine the association between dietary habits and prehypertension among Indonesian young adults at Prof. Dr. R. D. Kandou Hospital. The statistical analysis was performed with SPSS

\section{RESULTS}

There were 111 medical students as subjects in this study. Table 1 showed the ranges of age and blood pressure (SBP and DBP) as well as waist circumference (WC) of the subjects. As many as $22.5 \%$ of subjects had blood pressure levels within the range of prehypertension (Figure 1).

Table 1. Age and blood pressure of the subjects

\begin{tabular}{cccc}
\hline & n & Min-Max & Mean (SD) \\
\hline $\begin{array}{c}\text { Age } \\
\text { (years) }\end{array}$ & 111 & $20-30$ & $24.57 \pm 2.92$ \\
$\begin{array}{c}\text { SBP } \\
(\mathrm{mm} \mathrm{Hg})\end{array}$ & 111 & $100-135$ & $115.41 \pm 10.6$ \\
$\begin{array}{c}\mathrm{DBP} \\
(\mathrm{mm} \mathrm{Hg})\end{array}$ & 111 & $60-85$ & $74.32 \pm 7.37$ \\
\hline
\end{tabular}

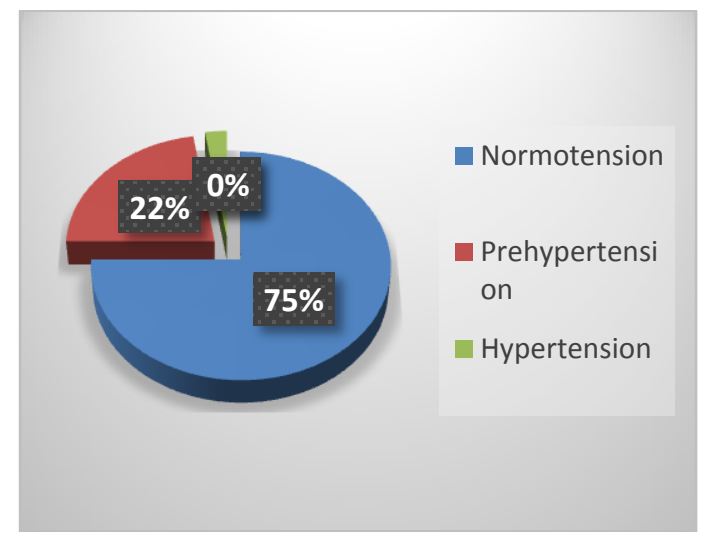

Figure 1. Distribution of blood pressure

Chi-square analysis revealed that junk food consumption (OR=3.152; 95\% CI $=1.253-7.925)$, and soft drink consumption $(\mathrm{OR}=4,747 ; 95 \% \mathrm{CI}=1,797-12,539)$ were the risk factors of prehypertension. Therefore, junk food and soft drink consumption were the risk factors of prehypertension among these medical students (Table 2). 
Table 2. Risk factors of prehypertension among medical students in Sam Ratulangi University

\begin{tabular}{rccc}
\hline Risk Factor & Odds Ratio & $\mathbf{9 5 \%}$ CI & $\boldsymbol{P}$ value \\
\hline Junk food consumption & 3.152 & $1.253-7.925$ & 0.023 \\
Soft drink consumption & 4.747 & $1.797-12.539$ & 0.002 \\
\hline
\end{tabular}

The Framingham Heart Study indicated that men and women with high normal blood pressure had a more than 2fold increase in relative risk for CVD compared with those who had optimal blood pressure. ${ }^{5,6}$ Some adolescents with prehypertension already demonstrate evidence of target organ damage, especially left ventricular hypertrophy $(\mathrm{LVH})$. This state $(\mathrm{LVH})$ is the most widely recognized abnormality attributed to high blood pressure in children. ${ }^{10}$

Previous studies found that subjects with prehypertension were also noted to have increased carotid artery intima-media thickness and arterial stiffness. ${ }^{11}$ Vascular abnormalities have also been reported in other prehypertensive populations. ${ }^{12}$

In this cross sectional study, $22.5 \%$ of subjects were identified to have prehypertension. This value is lower than the rate reported in a rural area in West Java Province $(34.2 \%){ }^{13}$ A similar rate was found in a survey in China $(21.9 \%){ }^{14}$ Overall in Malaysia, the prevalence of prehypertension is in the range of 34\%$37 \% .{ }^{15}$ Two studies performed in Malaysia among young adults aged 18-29 years old demonstrated a prevalence of prehypertension of $34 \%{ }^{11}$ and $30.1 \%{ }^{16}$ However, both of these studies and present study were conducted among university students located in an urban area and did not truly represent the general population.

The increasing prevalence of hypertension and prehypertension in rural area is the consequence of adoption of Western lifestyle with rapid urbanisasition. Dietary intake of higher sodium and lower potassium are widespread. ${ }^{17}$ The transition to adulthood is a complex process in which youth who have been dependent on parents throughout childhood start taking definitive steps to achieve measures of financial, residential, and emotional independence, and to take on more adults roles as citizen, spouse, parent, and worker. ${ }^{18}$ Clinical and academic challenges of medical students may have adverse effect on their lifestyle, predisposing vulnerable subjects to elevated blood pressure. ${ }^{8}$ They mostly prefer to take a lunch with meals eaten away from home than to having a home-prepared meal. Eating away from home is linked to higher total energy, fat and salt intake, lower micronutrient intake, and becoming overweight or obese, which may modulate increased blood pressure. ${ }^{19,20}$

In this study, dietary habits (junk food and soft drink consumption) were the risk factors of prehypertension $(P=0.023$ for junk food and $P=0.002$ for soft drink consumption). A lot of our subjects with prehypertension were found to be indulging in adverse dietary practices such as added salt and pickle intake, using butter in their meals, and eat junk food. Higher salt intake is associated with higher blood pressure. Intersalt study which investigated the association between $24 \mathrm{~h}$ sodium excretion and blood pressure revealed that a higher sodium intake by $2.3 \mathrm{mg} /$ day was reflected in higher SBP 3-6 mm $\mathrm{Hg}^{21}$ Moreover, Kini et $\mathrm{al}^{22}$ found that intake of extra salt in meals was associated with prehypertension among young adults in Coastal Villages of Southern India.

Other study also found the association of prehypertension with meals eaten away from home in young adults in Singapore. ${ }^{23}$ In a similar study carried out in Bihar among 15-19 year adolescents by Kumar et $\mathrm{al}^{24}$ hypertension was significantly associated with type of diet $(P<0.001)$ and additional salt intake $(P=0.008)$. Additional salt intake in the form of papad/pickle more than twice a week was having a significantly relationship with hypertension 
$(\mathrm{OR}=0.59 ; 95 \% \mathrm{CI}=0.38-0.90 ; P=0.008) .{ }^{24}$

The Dietary Approaches to Stop Hypertension (DASH) which uses a diet that rich in fruits, vegetables, fibers, nuts, low-fat dietary products, and low saturated fats, induced a significant lowering of blood pressure in subjects with high blood pressure. $^{25}$ Our findings, in most of prehypertensive subjects that weekly consumption of junk food and soft drink was common while daily consumption of fruits and vegetables was uncommon, indicate that lifestyle modification would probably be the most effective management of prehypertension in young adults.

We suggest that promotion of healthier food habits among university students is likely to be beneficial for prevention of prehypertension and hypertension. It is important for food providers at university campuses to prepare healthier meals, therefore, we can prevent this disease.

The limitation of our study is that our subjects were conducted among university students located in an urban area and did not truly represent the general population.

\section{CONCLUSION}

Incidence of prehypertension in this study was high $(22.5 \%)$. Junk food consumption and soft drink consumption were the risk factors of prehypertension among medical students of Sam Ratulangi University, Manado; albeit, these risk factors are modifiable by changing their lifestyles.

\section{REFERENCES}

1. Chobania AV, Bakris GL, Black HR, Chusman WC, Green LA, Izzo JL, et al. Seventh report of the Joint National Committee on prevention, detection, evaluation, and treatment of high blood pressure. Hypertension. 2003;42(6): 1206-52

2. Lewington S, Clarke R, Qizilbash N, Peto R, Collins R. Age specific relevance of usual blood pressure to vascular mortality. Lancet. 2002;360:1903-13.

3. US Department of Health and Human Services: Healthy people 2010. With Understanding and Improving Health and Objectives for Improving Health
Vol 2 (2nd ed). Washington, DC; US Dept. of Health and Human Services, 2000.

4. Ferguson TS, Younger N, Tulloch-Reid MK, Lawrence-Wright MB, Forrester TE, Cooper RS, et al. Progression from prehypertension to hypertension in a Jamaican cohort: incident hypertension and its predictors. West Indian Med J. 2010;59(5):486-93

5. Asmathulla S, Rajagovindan D, Sathyapriya V, Pai B. Prevalence of prehypertension and its relationship to cardiovascular disease risk factors in Puducherry. Indian J Physiol Pharmacol. 2011;55(4):343-50.

6. Pletcher M, Bibbins-Domingo $\mathrm{K}$, Lewis $\mathrm{C}$, Wei G, Sidney C, Carr J, et al. Prehypertension during young adulthood. Ann Intern Med. 2008;149(2): 91-9.

7. Gupta R. Trends in hypertension epidemiology in India. J Human Hypertens. 2004;18:73-8.

8. Senthil S, Krishndasa. Pre-hypertension in apparently healthy young adults: incidence and influence of haemoglobin level. J Clin Diagn Res. 2015;9(11):CC10-2.

9. Jayashri B, Sahsrabudhhe A, Arora V, Dabhi H. Pre-hypertension and hypertension and its determinants among school adfolescents of rural area of indore - a cross sectional study. National Journal of Community Medicine. 2015;6(2):358-63.

10. Redwine KM, Daniels SR. Prehypertension in adolescents: risk and progression. $\mathbf{J}$ Clin Hypertens (Greenwich). 2012; 14(6):360-4

11. Urbina EM, Khoury PR, McCoy C, Daniels SR, Kimball TR, Dolan LM. Cardiac and vascular consequences of pre-hypertension in youth. J Clin Hypertens (Greenwich). 2011;13:33242.

12. Drukteinis JS, Roman MJ, Fabsitz RR, Lee ET, Best LG, Russel M, et al. Cardiac and systemic hemodynamic characteristics of hypertension and prehypertension in adolescents and young adults: the Strong Heart Study. Circulation. 2007;115:221-7.

13. Widjaja FF, Santoso LA, Barus NRV, Pradana GA, Estetika C. Prehyper- 
tension and hypertension among young Indonesian: adults at a primary health care in a rural area. Med $\mathbf{J}$ Indos. 2013;22(1):39-45.

14. He J, Neal B, Gu D, Suriyawongpaisal P, Xin $X$, Reynolds $R$, et al. International collaborative study of cardiovascular disease in Asia: design rationale, and preliminary results. Ethn Dis, 2004;14(2):260-8.

15. Intiaz MH, Salmiah M, Saliluddin S. Prehypertension and its associated factors among students in a pre-university college in Malaysia. Inter J Pub Health Clin Sci. 2016;3(5):70-85.

16. Balami A, Salmiah $M$, Nor Afiah $M$. Psychological determinants of prehypertension among first year undergraduate students in a public university in Malaysia. Malaysian J Pub Health Med. 2014;14(2):67-76.

17. Ennis IL, Gende OA, Cingolani HE. Prevalence of hypertension in 3154 young students. Medicina (B Aires). 1998;58:483-91.

18. Jekielek S, Brown B. The transition to adultshood: characteristics of young adults age 18 to 24 in America. The Annie E. Casey Foundation, Population Reference Bureau, and Child Trends, 2005.

19. Lachat $C$, Nago E, Verstraeten $R$, Robertfroid D, Van Camp J, Kolsteren P. Eating out of home and its association with dietary intake; a systematic review of the evidence.
Obes Rev. 2012;13:329-46.

20. Nago ES, Lachat CK, Dossa RA, Kolsteren PW. Association of out-of-home eating with anthropometric changes: a systematic review of prospective studies. Crit Rev Food Sci Nutr. 2014; 54:1103-16.

21. Starnler J. The INTERSALT Study: background, methods, findings, and implications. Am J Clin Nutr. 1997; 65(Suppl 2):626S-42S.

22. Kini S, Kamath VG, Kulkarni MM, Kamath A, Shivalli S. Prehypertension among young adults (20-30 years) in coastal villages of udupi district in Southern India: an alarming scenario. PlosOne 11(4). doi:10,1371/ journal.pone. 0154538

23. Seow DYB, Haaland B, Jafar TH. The association of prehypertension with meals eaten away from home in young adults in Singapore. Am J Hypertens. 2015;28(10):1197-200.

24. Kumar A, Atul K, Apeksha P, Neha G, Deba PB. Prevalence and risk factors associated with hypertension in children and adolescents. Pediatric onCall J. 2015;12(2). DOI:10.7199/ ped.oncall.2015.34

25. Appel LJ, Moore TJ, Obarzanek E, Vollmer WM, Svetkey LP, Sacks FM, et al. A clinical trial of the effects of dietary patterns on blood pressure. DASH Collaborative Research Group. N Engl J Med, 1997;336:1117-24. 